\title{
Digestibility Studies on Napier (Merker) Grass (Pennisetum purpureum), Giant Pangola Grass (Digitaria valida Stent), and Signal Grass (Brachiaria brizantha)
}

\section{J. A. Arroyo and L. Rivera Brenes ${ }^{1}$}

\section{INTRODUCTION}

The data reported in this paper are the results of digestion trials performed on Napier (Merker) grass (Pennisetum purpureum), Giant Pangola grass (Digitaria valida Stent), and Signal grass (Brachiaria brizantha). Digestion trials and palatability tests were conducted concurrently with these forages. Palatability results were reported separately $(6)^{2}$.

Napier (Merker) grass was introduced into the Island by the Agricultural Experiment Station of the University of Puerto Rico in 1934, from Mississippi. It is the most important soilage grass actually grown in the Island. Besides its high yield per acre, from 70 to over 100 tons per acre per year $(8,10)$, its high palatability is well known to all farmers $(7)$.

Giant Pangola grass was introduced from Cuba by this Station in 1957. After some fieldwork it looks like a promising forage grass and is being evaluated accordingly. It was found as palatable as Napier (Merker) grass (6).

Signal grass was also introduced into Puerto Rico by this Station from Ceylon in 1957 (3). It is widely used in that country. It has a number of good characteristics which make it also look promising. It is as palatable as Napier (Merker) grass and as Giant Pangola (6). This grass has been described as a different strain from the one found in Puerto Rico (4).

This paper reports the values for digestible energy, digestible protein, and total digestible nutrients for these two new grasses as compared with Napier grass (Merker). These criteria are recommended by Swift (9).

\section{PROCEDURE}

The experiment consisted of two trials on each of the three grasses with a 7-day prefecding period and a 5-day collection period. Three groups of three cows were used for each trial.

The grasses were about 50 days old at the first trial and about 80 days at the second. That is, for the first digestion trial the grasses were green

1 Assistant Biochemist I and Head, respectively, Animal Husbandry Department, Agricultural Experiment Station, University of Puerto Rico, Río Piedrus, P'R.

2 Italic numbers in parentheses refer to Literature Cited. p. 155-6. 
and tender and less mature than for the second. Each trial is reported separately and then the two are averaged.

The grasses were fertilized at the rate of 400 pounds of $\mathrm{N}, 300$ of $\mathrm{P}_{2} \mathrm{O}_{5}$, and 300 of $\mathrm{K}_{2} \mathrm{O}$ per acre per year, and one-sixth of that amount was applied to the plots as if they were going to be cut every 2 months.

The needed daily forage from each grass was cut in the morning, chopped in a silage-chopper, and fed to the cows in three or four servings during the day. All forage offered, as well as that refused, was carefully collected and weighed for each 24-hour-period for 5 consecutive days. All animals were weighed every day in the morning, around 7:00 a.m. and were kept continuously in the stanchions during the collection period.

A 25-gm. sample of fecal material was collected twice daily, in the morning and in the afternoon. The samples were accumulated in the same jar to a total of $250 \mathrm{gm}$. throughout the collection period. A $500-\mathrm{gm}$. sample of each roughage material was collected once a day after the grass was chopped and thoroughly mixed with a shovel. Fecal and roughage samples were airdried at $70^{\circ} \mathrm{C}$. for 5 days for dry-matter determinations.

The dried samples were ground in a Wiley mill and placed in glass bottles. Crude-protein determinations were made according to A.O.A.C. Official Methods (1). Calorimetric determinations were made according to the Parr oxygen-bomb combustion method (2). A total of 42 roughage and 18 fecal samples were analyzed.

Conversion of digestible energy to T.D.N. was made according to Swift (9).

\section{RESULTS AND DISCUSSION}

The results of each digestion trial are reported separately for comparison purposes, and then the data are averaged.

Table 1 presents the green-roughage and dry-matter consumed, as well as the feces and dry matter excreted for the first and second digestion trials. Generally speaking, the consumption of dry matter increased in the second digestion trial. This, of course, was expected, because of the condition of the grasses when more mature, principally Napier.

The consumption of green Giant Pangola is to be noted. It increased in the second trial, as did the dry matter. The grasses were about 50 days old for the first digestion trial and about 80 for the second. This implies a reduction in palatability due to coarseness of the material. It was true for Napier and Signal grasses but not for Giant Pangola.

Table 2 presents the dry matter, crude protein, and gross energy for the three grasses and also for the fecal samples of the same, first and second digestion trials. As can be seen Giant Pangola and Signal grasses contain more dry matter per pound of green grass than Napier. Dry-matter content 
for these two grasses did not vary markedly from one age, 50 days, to the other, 80 days. The dry-matter content of Napier increased as expected. Crude protein naturally decreased with age for the three grasses.

TABLE 1.-Green roughage and dry matter (pounds) consumed, and feces and dry matter eliminaled per day during the 2 digestion trials on

$\$$ grasses at different ages, using $\$$ cows

\begin{tabular}{c|c|c|c|c}
\hline Grass & $\begin{array}{c}\text { Average roughage } \\
\text { consumption per } \\
\text { day }\end{array}$ & $\begin{array}{c}\text { Average dry- } \\
\text { matter consump- } \\
\text { tion per day }\end{array}$ & $\begin{array}{c}\text { Average fecal } \\
\text { elimination } \\
\text { per day }\end{array}$ & $\begin{array}{c}\text { Average dry- } \\
\text { matter elimina- } \\
\text { tion per day }\end{array}$ \\
\hline
\end{tabular}

First digestion trial on 50-day-old grasses

\begin{tabular}{l|r|r|r|l}
\hline Napier (Merker) & 109.87 & 13.66 & 42.87 & 6.82 \\
Giant Pangola & 74.00 & 15.67 & 42.17 & 7.28 \\
Signal & 70.27 & 14.76 & 43.60 & 7.78 \\
\hline
\end{tabular}

Second digestion trial on 80-day-old grasses

\begin{tabular}{l|l|l|l|l}
\hline Napier (Merker) & 78.7 & 15.42 & 48.67 & 7.81 \\
Giant Pangola & 77.07 & 16.62 & 48.30 & 7.30 \\
Signal & 61.30 & 14.07 & 38.60 & 6.77 \\
\hline
\end{tabular}

TABLE 2.-Dry-matter, crude-prolein, and gross-energy values for Napier (Merker), Giant Pangola, and Signal grasses of 2 different ages, and $\$$ fecal samples (dry basis), for the first and second digestion trials, using 7 and $\$$ cows, respectively

\begin{tabular}{|c|c|c|c|c|c|c|}
\hline \multirow{2}{*}{ Grass } & \multicolumn{3}{|c|}{ Forages } & \multicolumn{3}{|c|}{ Feces } \\
\hline & $\underset{\text { matter }}{\text { Dry }}$ & $\begin{array}{c}\text { Crude } \\
\text { protein }\end{array} \mid$ & Gross energy & $\underset{\text { matter }}{\text { Dry }}$ & $\begin{array}{c}\text { Crude } \\
\text { protein }\end{array}$ & Gross energy \\
\hline
\end{tabular}

First digestion trial on 50-day-old grasses

\begin{tabular}{l|c|c|c|c|c|c|c|c}
\hline & Percenl & Percent & Cal./gm. & Therms & Percent & Percent & Cal./gm. & Therms \\
Napier (Merker) & 12.43 & 8.30 & 4.71 & 2.14 & 15.96 & 8.04 & 4.87 & 2.21 \\
Giant Pangola & 21.17 & 6.29 & 5.00 & 2.27 & 17.29 & 7.47 & 5.16 & 2.34 \\
Signal & 21.00 & 6.07 & 5.43 & 2.46 & 17.87 & 7.33 & 4.88 & 2.16 \\
\hline
\end{tabular}

Second digestion trial on 80-day-old grasses

\begin{tabular}{l|l|l|l|l|l|l|l|l}
\hline Napier (Merker) & 19.59 & 5.23 & 5.21 & 2.37 & 16.05 & 6.15 & 5.46 & 2.48 \\
Giant Pangola & 21.56 & 5.43 & 5.48 & 2.49 & 14.97 & 6.96 & 5.21 & 2.36 \\
Signal & 22.95 & 4.66 & 5.39 & 2.47 & 17.61 & 5.87 & 5.39 & 2.44 \\
\hline
\end{tabular}

Table 3 presents the digestible-energy, digestible-protein, and total digestible-nutrient values for the two trials. Both Giant Pangola and Signal grass had more digestible energy and total digestible nutrients than Napier 
in the two digestion trials. Napier, though, was higher in digestible protein in the first trial, when younger. Apparently age did not affect the digestibility of Giant Pangola, the results of these trials show an increase. These

TABLE 3.-Digestible-energy, digestible-protein, and T.D.N. values for Napier (Merker), Giant Pangola, and Signal grasses of different ages for the first and second digestion trials, using $\$$ cows

\begin{tabular}{c|l|l|l|c}
\hline Grass & Digestible energy & T. D. N. & $\begin{array}{c}\text { Diges- } \\
\text { tible } \\
\text { protein }\end{array}$ & $\begin{array}{c}\text { Diges- } \\
\text { tible } \\
\text { coeffici- } \\
\text { ent }\end{array}$ \\
\hline
\end{tabular}

First digestion trial on 50-day-old grasses

\begin{tabular}{l|c|c|c|c|c|c|c}
\hline & Cal. & Therms & Percent & Pounds & Percent & Percent & Percent \\
Napier (Merker) & $14,130.84$ & 14.13 & 48.38 & 7.11 & 52.05 & 4.28 & 51.63 \\
Giant Pangola & $18,445.34$ & $\mathbf{1 8 . 4 4}$ & $\mathbf{5 2 . 0 0}$ & $\mathbf{9 . 2 8}$ & $\mathbf{5 9 . 2 2}$ & $\mathbf{2 . 8 2}$ & 44.48 \\
Signal & $19,149.90$ & 19.15 & $\mathbf{5 2 . 6 3}$ & $\mathbf{9 . 6 4}$ & $\mathbf{6 5 . 3 1}$ & $\mathbf{2 . 2 1}$ & $\mathbf{3 6 . 3 8}$ \\
\hline
\end{tabular}

Second digestion trial on 80-day-old grasses

\begin{tabular}{l|r|r|r|r|r|r|r}
\hline Napier (Merker) & $17,113.80$ & 17.11 & 46.92 & 8.61 & 55.84 & 2.13 & 40.82 \\
Giant Pangola & $24,082.25$ & 24.08 & 58.24 & 12.12 & $\mathbf{7 2 . 9 2}$ & $\mathbf{2 . 4 3}$ & 44.78 \\
Signal & $17,863.53$ & 17.86 & 51.88 & 8.99 & 63.89 & 1.84 & 39.48 \\
\hline
\end{tabular}

TABLE 4.-Digestible-energy, digestible-protein, and T.D.N. values for Napier (Merker), Giant Pangola, and Signal grasses, of different ages showing averages of 2 trials using 6 cows

\begin{tabular}{|c|c|c|c|c|c|c|c|}
\hline \multirow[t]{2}{*}{ Grass } & \multicolumn{3}{|c|}{ Digestible energy } & \multicolumn{2}{|c|}{ T.D.N. } & \multirow{2}{*}{ 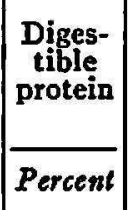 } & \multirow{2}{*}{$\begin{array}{c}\begin{array}{c}\text { Digestion } \\
\text { coeffici- } \\
\text { ent }\end{array} \\
\text { Percent }\end{array}$} \\
\hline & Cals. & Therms & Percent & Pourds & Percens & & \\
\hline Napier (Merker) & $15,622.32$ & 15.62 & 47.65 & 7.86 & 5.395 & 3.21 & 46.23 \\
\hline Giant Pangola & $21,263.79$ & 21.26 & 55.12 & 10.70 & 66.07 & 2.62 & 44.63 \\
\hline Signal & $18,506.72$ & 18.51 & 52.26 & 9.32 & 64.60 & 2.03 & 37.93 \\
\hline
\end{tabular}

findings are under further investigation. Palatability was not affected by age either, as shown in table 1.

Average results of the two digestion trials are given in table 4 . The drymatter content of the two new grasses, Giant Pangola and Signal, is very important from the nutritional point of view under our conditions. It is very hard to make any dairy cow eat enough dry matter for maintenance and derive a reasonable part of its production from young Napier (Merker), Guinea, or Pará grass, because their moisture contents are over 80 percent. 
With these two new grasses the situation can be improved considerably; see table 1 .

More work on evaluation of these two grasses is being carried out.

\section{SUMMARY}

Digestible energy and digestible protein were determined for Giant Pangola (Digitaria valida Stent), Signal (Brachiaria brizantha), and Napier (Merker) (Pennisetum prupureum) grasses. Total digestible nutrients were also calculated. Digestible protein for Napier (Merker), Giant Pangola, and Signal grasses were $3.21,2.62$, and 2.03 percent. Total digestible nutrients in the same order were, $53.95,66.07$, and 64.60 percent.

Two digestion trials were made, one when the grasses were about 50 and the other when they were about 80 days old. The average digestion coeffcient for energy for Napier (Merker) was $\mathbf{4 7 . 6 5}$ percent, for Giant Pangola 55.12 , and for Signal grass 52.26.

Both Giant Pangola and Signal grasses are much higher in dry-matter content than Napier (Merker) at 50 days of age, a very important characteristic nutritionally speaking.

\section{RESUMEN}

A las yerbas Pangola Gigante, Napier (Merker) y Estación se les determinó la energía y proteína digeribles. También se les calculó su cantidad total de nutrientes digeribles.

Se hicieron dos pruebas de digestibilidad; una cuando tenían alrededor de 50 días de sembradas y otra a los 80 días, más o menos.

El promedio de los coeficientes de digestibilidad para energía fue como sigue: Napier (Merker) 47.65 por ciento; Pangola Gigante 55.12 por ciento; y Estación 52.26. El porcentaje de proteína digerible fue, para la Napier (Merker) 3.21, para la Pangola Gigante 2.62 y para la Estación 2.03. El porcentaje total de nutrientes digeribles fue $53.95,66.07$ y 64.60 para las tres yerbas en el mismo orden respectivo.

Tanto la Pangola Gigante, como la Estación contienen mayor cantidad de materia seca que la Napier (Merker), a los 50 días de sembradas. Este es un carácter muy importante de estas yerbas desde el punto de vista nutricional.

\section{LITERATURE CITED}

1. Association of Official Agricultural Chemists, Methods of Analysis, 8th ed., Washington, D.C., 1955.

2. Oxygen Bomb Calorimetry and Oxygen Bomb Combustion Methods, Manual 120, Parr Instrument Co., Moline, Ill., 1948.

3. Rivera Brenes, L., Informe Semestral enero l a julio 31 de 1959, Depto. de Zootec- 
nia, Estación Experimental Agrícola, U.P.R., Río Piedras, P.R., 25 de agosto de 1959.

4. - Informe Semestral agosto I de 1959 a enero 31 de 1960, Depto. de Zootecnia, Estación Experimental Agrícola, U.P.R., Río Piedras, P.R., 12 de julio de 1960.

5. - Informe Semestral febrero l a junio 30 de 1960, Depto. de Zootecnia, Estación Experimental Agrícola, U.P.R., Río Piedras, P.R., 12 de julio de 1960.

6. Rivera Brenes, L., Arroyo, J. A., Cestero, H., and Sierra, A., Palatability tests on Giant Pangola grass (Digitaria valida Stent) and Signal grass (Brachiaria brizantha) as compared with Napier (Merker) grass (Pennisetum purpureum), J. Agr. Univ. P.R. 45(3) 147-50, 1961.

7. Rivera Brenes, L., Herencia, J., Arroyo, J. A., and Cabrera, J. I., Palatability trials on Merker grass (Pennisetum purpureum), Venezuela grass (Paspalum fasciculatum), and plantain pseudostalks, (Musa paradisiaca), J. Agr. Univ. P.R., 43(4) 249-54, 1959.

8. Rivera Brenes, L., Technical and Economic Aspects of Roughage Production in Puerto Rico, Agr. Exp. Sta. Univ. P.R., Río Piedras, P.R., Tech. Bul. 12, Sept. 1953.

9. Swift, R. W., The Nutritive Evaluation of Forages, Pa. State Univ., University Park, Pa., Bul. 615, Jan. 1957.

10. Vicente-Chandler, José, Silva, Servando, and Figarella, Jacinti, Effects of nitrogen fertilization and frequency of cutting on the yield and composition of Napier grass in Puerto Rico; Effects of nitrogen fertilization and frequency of cutting on the yield and composition of Guinea grass in Puerto Rico; and Effects of nitrogen fertilization and frequency of cutting on the yield and composition of Para grass in Puerto Rico, J. Agr. Univ. P.R. 43(4) 215-48, 1959. 